\title{
Introduction, connection, application, reflection, and extension (ICARE) learning model: The impact on students' collaboration and communication skills
}

\author{
Parsaoran Siahaan ${ }^{1}$, Ermawati Dewi ${ }^{2}$ and Endi Suhendi ${ }^{3 *}$ \\ ${ }^{1,3}$ Physics Education Department, Universitas Pendidikan Indonesia, Bandung, Indonesia \\ ${ }^{2}$ Master of Physics Education, School of Postgraduate, Universitas Pendidikan Indonesia, Bandung, Indonesia
}

*Corresponding Address: endis@upi.edu

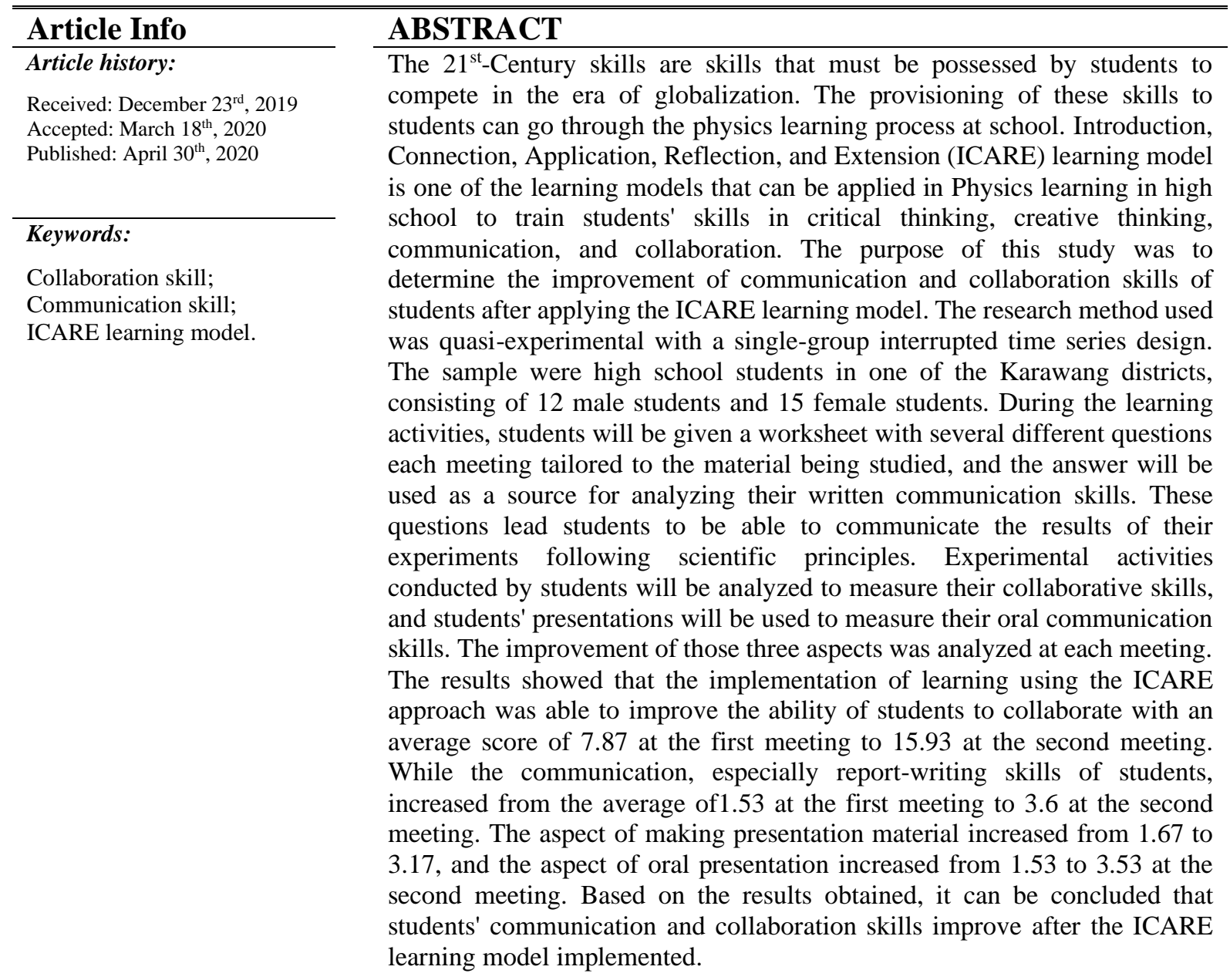

(C) 2020 Physics Education Department, UIN Raden Intan Lampung, Indonesia.

\section{INTRODUCTION}

The development of the $21^{\text {st }}$ century brings a huge impact on various fields of life. The $21^{\text {st }}$ century is marked by the development of knowledge, technology, and the availability of a lot of information and the rapid development of computing into its challenges. This also becomes a challenge for the education system to be able to prepare human resources with good competitive quality in the global era. This learning experience must empower students as 
individuals and citizens as agents of change that are responsible, creative, innovative, and able to contribute to society, nation, and world civilization (Ridwan et al., 2017). The demand for skills that students must possess in this era is that students have critical, creative, collaborative, and innovative thinking skills. Various models and strategies for practicing $21^{\text {st }}$-century skills have often been carried out, given the importance and urgency needed by individuals in each country to face global competition (Qian \& Clark, 2016). Qian \& Clark, (2016) practiced $21^{\text {st }}$-century skills using game-based learning. The results of this study showed the profile of students 'creative skills reached $70 \%$, but for students' collaborative and communication skills, it was less than $20 \%$. Tunkham et al. (2016) researched STEM learning to improve $21^{\text {st }}$-century skills. The results of this study showed an increase in the category of creative thinking skills, but this study did not train students' communication and collaboration skills.

One of the learning models that can encourage and increase students' activeness is the ICARE learning model. ICARE stands for Introduction, Connect, Apply (application), Reflect, and Extend (Salyers et al., 2010). The ICARE learning model uses a constructivist approach with the teacher as a facilitator. In the learning process, ICARE focuses on working skills so that it benefits both students and teachers (Chaiphugdee, 2019). The ICARE model provides students with the opportunity to learn more actively and directed based on the phases in the ICARE learning model (Anagnostopoulou et al., 2010). These learning models have the advantages of 1) At the introduction stage, students are more motivated to increase curiosity through referral questions related to the material to be studied; 2) at the connection stage, which is the stage of embedding concepts. Students are trained to build their knowledge so that they can grow high-level skills, such as creative thinking and problem-solving skills. In this phase, students are trained to communicate to express ideas while constructing their knowledge; 3) at the application stage, students are given problems in the real world context which is open-ended to be solved by using the concepts they have gained at the connection and introduction stages. At this stage, collaboration is needed for students to solve problems through practicum activities while testing how well can students understand about the concept after practicing; 4) in the reflection and extension stages students are allowed to repeat briefly the learning that has been done so that students' knowledge becomes stronger and enduring; 5) the teacher is more flexible in designing the learning so that it can change students' learning experience (Byrum, 2013). Another advantage of the ICARE learning model is that the stages are mutually sustainable, making it easier for students in the active learning process (Sinuraya et al. 2019).

Myriads of studies have shown that the use of the ICARE learning model has a positive impact. Carni et al. (2016) conducted a study by implementing the ICARE approach to the dynamic electrical material of high school students. The results of the final analysis of his research showed that the application of the ICARE approach generally improved students' creative thinking skills apply this approach to nursing students to evaluate and see the level of student satisfaction in using the framework (Salyers et al., 2010). Nursing students have been included in innovative learning, and this makes it easy for those in remote areas to remain able to learn and find out information about current professional knowledge. Asri et al. (2016) combine the ICARE learning model with science magic, which shows the profile of students' positive attitudes. Byrum (2013) applies ICARE learning to masters educational technology students, where the steps of the ICARE framework are constructive and easy to use for training participants to develop learning modules. Hansah et al. (2013) used the ICARE steps in learning Better Teaching and Learning 
(BTL) process skills to improve the learning activities of junior high school students. The results showed that the combination of PBL and ICARE could improve student learning activities, especially in: 1) listening and paying attention to teacher's explanations and friends' opinions with interests, and reading books calmly (listening, visual, emotional activities); 2) record the material explained and work on the exercise questions (writing activities); and 3) dare to ask questions, express opinions, answer questions, and make conclusions (verbal, mental, emotional activities) (Tikollah et al., 2019). ICARE learning model is more effective to be applied in group activities because the activities in the ICARE model are mutually sustainable and have clear instructions so that they are easily carried out.

The ICARE learning model provides students with more communication and collaboration facilities in the learning process. Through a process of communication and a good collaboration, of course, this can train and prepare a good quality of Human Resources (HR) that is competitive in the global era. In previous research, ICARE has succeeded in improving creative and critical thinking skills, which are part of $21^{\text {st }}$-century skills. In this study, students were trained in communication and collaboration skills through the ICARE learning model. The ICARE learning model has a coherent syntax making it easier for students to practice communication and collaboration skills. Figure 1 shows the relationship between ICARE, communication skills, and collaboration skills. In this article, we report the results of the implementation of the ICARE learning model in practicing student collaboration and communication skills.

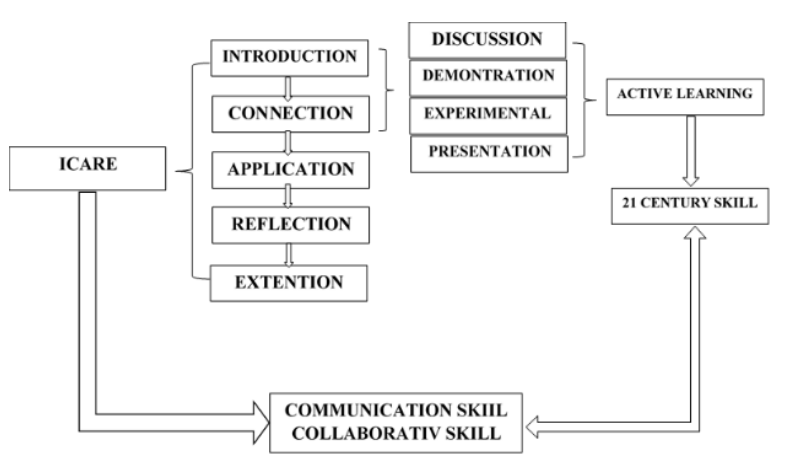

Figure 1. Relation of ICARE, collaborative and communicative skill

\section{METHODS}

The method used in this study was quasiexperimental with a single-group interrupted time series design (Creswell, 2014). In this study, researchers took measurements in a group after being given treatment. Treatments were held two times. Then the results were compared to see changes in treatment results. In the learning activities, students were given a student participant worksheet with several different questions each meeting tailored to the material being studied. These questions lead students to be able to communicate the results of their experiments following scientific principles. Figure 2 shows an example of the student worksheet.

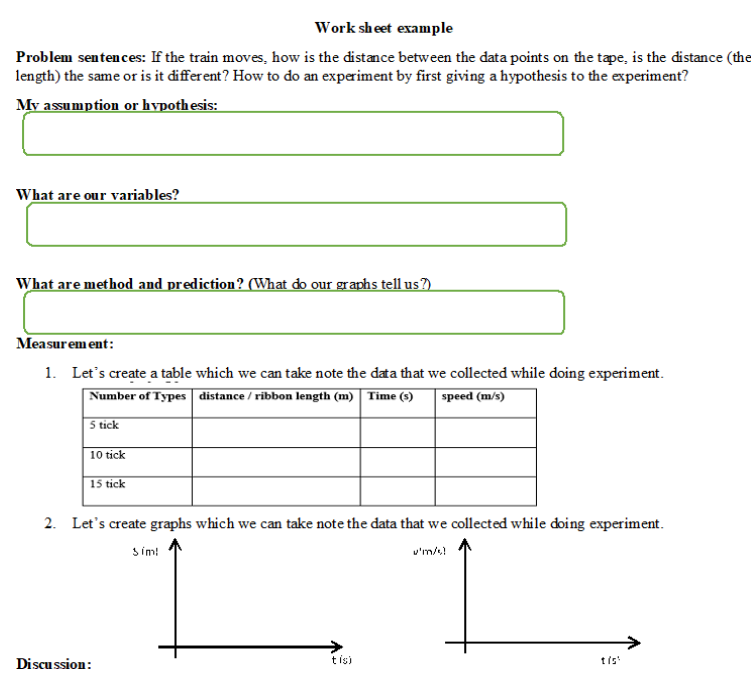

Figure 2. Example of student worksheet 
Experimental activities conducted by students were analyzed for collaborative skills. Meanwhile, oral communication skills were analyzed based on the results of the presentation. The three of those aspects' improvement profiles then was analyzed at every two meetings. The difference between the two meetings is the material they teach. The first meeting discusses linear motion with constant velocity, and the second meeting discusses linear motion with constant acceleration according to the applicable curriculum. This study involved high school students in grade $\mathrm{X}$ in one high school in Karawang regency, with a total of 27 students using a random sample class as its technique.

The ICARE learning model was applied in the learning process, where the first stage was the introduction. At this stage, the teacher taught subject matter by explaining the learning objectives, the expected results of learning, providing perceptions, and motivation related to the subject of the straight motion. The next stage was the connection. At this phase, the teacher gave some information through demonstrations in front of the class. Then he distributed student worksheets related to concepts that must be completed through the practicum process and making presentations. At this stage, students conducted group activities and discuss so that they can practice communication skills and collaboration skills that were assessed by the observer during the learning process. The next step was the application. Here, the teacher encouraged and made students apply the knowledge and skills they have acquired in the form of practice exercises. In the reflection phase, the teacher invited students to review what material has been learned. In the extension stage, students expand the material that has been obtained independently both through textbooks and other media in the form of homework. Communication and collaboration skills were trained at the connection stage through practical activities. Figure 3 illustrated the research flow of this study.

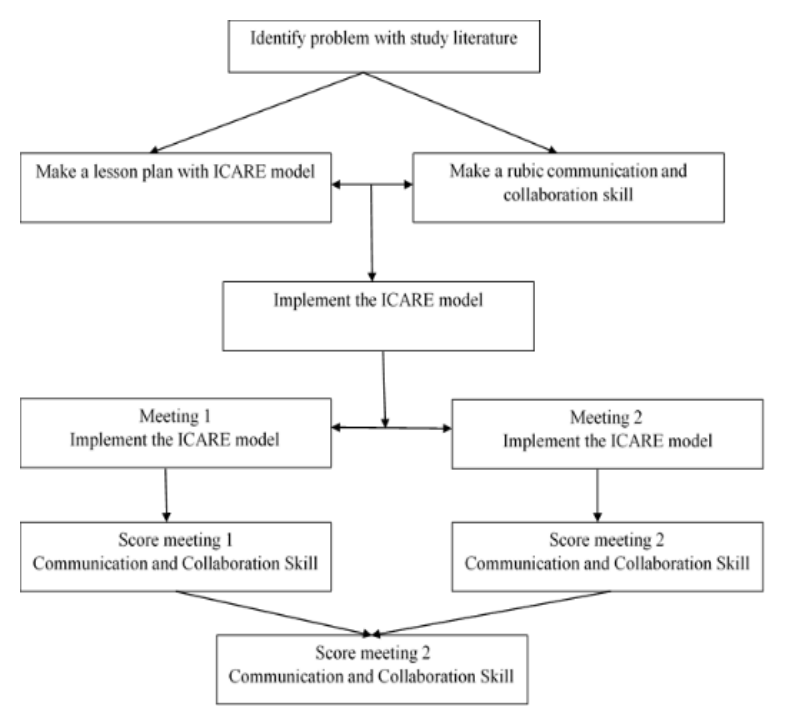

Figure 3. Research flow

Communication skills rubric was used to analyze students' communication skills, which were focused on scientific communication skills adapted from (SpektorLevy et al., 2008). Scientific communication skills consisted of two components, namely Scientific Writing and Knowledge presentation, which were trained during the learning process. From these two aspects, there were different ways of asserting according to the characteristics of the scientific component. For the scientific writing component, it was assessed based on the rubric assessment report of the practicum results, and for the knowledge presentation test was assessed based on the observation results of the presentation in class. Collecting collaboration skills was done through observation when students carried out the learning process in which there were practicum activities following the learning stages of ICARE. Students were assessed by observers. In this study, there are five observers, and each group was observed by one observer. The observer using a rubric in the form of collaborative skills rubric. Consisting of five aspects, namely: 1) Contribution; 2) Time management; 3) Problem solving; 4) Working with others; 5) Investigation techniques. This collaborative skills rubric was an adaptation of the International Reading Association, Read Write Think "Collaborative Work Skill 
Rubric." Each aspect was given a score of 1, 2,3 , and 4 with the lowest skill level given a score of 1 , and the highest was given a score of 4. After that, the total score was obtained by summing the scores of each aspect with a maximum score of 20 .

Furthermore, the data were processed using domain assessment psychomotor, which is then interpreted as a level of collaboration ability. Assessment Indicators for each rubric of collaboration skills are shown in Table 1. It was adjusted to the validated rubric, student's condition, and the observer. Thus the rubric created could meet the criteria for assessing collaboration skills.

Table 1. Example of collaboration skill rubric

\begin{tabular}{|c|c|c|c|c|}
\hline & 1 & 2 & 3 & 4 \\
\hline Contribution & $\begin{array}{l}\text { In a large } \\
\text { and small } \\
\text { group } \\
\text { discussion, } \\
\text { shares } \\
\text { helpful } \\
\text { idea. Leads } \\
\text { the } \\
\text { discussion } \\
\text { and makes a } \\
\text { strong to } \\
\text { effort to } \\
\text { contribute }\end{array}$ & $\begin{array}{l}\text { In a large } \\
\text { and small } \\
\text { group } \\
\text { discussion, } \\
\text { often } \\
\text { shares } \\
\text { helpful } \\
\text { ideas. } \\
\text { Clearly } \\
\text { strives to } \\
\text { participate }\end{array}$ & $\begin{array}{l}\text { In a large } \\
\text { and small } \\
\text { group } \\
\text { discussion, } \\
\text { often } \\
\text { shares } \\
\text { helpful } \\
\text { ideas. } \\
\text { Makes the } \\
\text { required } \\
\text { effort to } \\
\text { participate } \\
\text { but no } \\
\text { more }\end{array}$ & $\begin{array}{l}\text { In large } \\
\text { and small } \\
\text { group } \\
\text { discussio } \\
\text { ns, rarely } \\
\text { shares } \\
\text { helpful } \\
\text { ideas. } \\
\text { Participat } \\
\text { es } \\
\text { minimall } \\
\text { y or not } \\
\text { at all }\end{array}$ \\
\hline $\begin{array}{l}\text { Time } \\
\text { Management }\end{array}$ & $\begin{array}{l}\text { Completes } \\
\text { assignments } \\
\text { on time } \\
\text { throughout } \\
\text { the project. } \\
\text { It does not } \\
\text { cause the } \\
\text { group to } \\
\text { change } \\
\text { deadlines or } \\
\text { reassign } \\
\text { work } \\
\text { because of } \\
\text { lateness. }\end{array}$ & $\begin{array}{l}\text { Usually } \\
\text { completes } \\
\text { assignment } \\
\mathrm{s} \text { on time } \\
\text { throughout } \\
\text { the project. } \\
\text { Does not } \\
\text { cause the } \\
\text { group to } \\
\text { change the } \\
\text { deadline or } \\
\text { reassign } \\
\text { work } \\
\text { because of } \\
\text { lateness }\end{array}$ & $\begin{array}{l}\text { May put } \\
\text { things off } \\
\text { but turns } \\
\text { assignment } \\
\mathrm{s} \text { in on } \\
\text { time. Does } \\
\text { not cause } \\
\text { the group } \\
\text { to change } \\
\text { the } \\
\text { deadline or } \\
\text { reassign } \\
\text { work } \\
\text { because of } \\
\text { lateness }\end{array}$ & $\begin{array}{l}\text { Routinel } \\
\text { y misses } \\
\text { deadlines } \\
\text {, put off } \\
\text { work, } \\
\text { and } \\
\text { causes } \\
\text { the group } \\
\text { to change } \\
\text { deadlines } \\
\text { or } \\
\text { reassign } \\
\text { work } \\
\text { because } \\
\text { of } \\
\text { lateness }\end{array}$ \\
\hline
\end{tabular}

\section{RESULTS AND DISCUSSION}

Data acquisition scores of students' communication skills were obtained based on observations. The assessment of students' scientific communication skills assessed included the preparation of practical writing reports, presentation materials, and oral presentations (knowledge presentation). Each group was observed by an observer. Observations were made during the learning process that implemented the ICARE learning model. Each component or aspect of scientific skills was shown in the learning activities straight motion. The results of the achievement of two aspects of skills, namely, scientific writing and knowledge presentation aspects based on report preparation indicators, presentation material, and oral presentations in the learning process using the ICARE learning model.

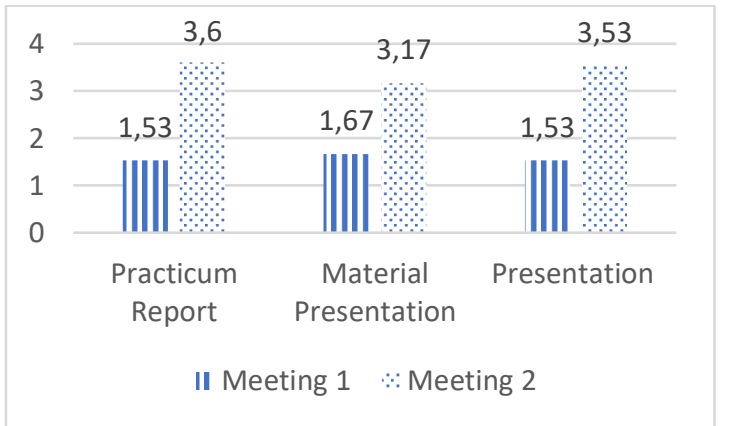

Figure 4. Average score of each indicator of communication skills

Figure 4 shows the average achievement score of each indicator of communication skills from the first and second meetings with a maximum score of 4 . Based on Figure 4, it can be seen that communication skills for each aspect increased from the first meeting to the second meeting. At the first meeting, the highest average score was found in the making of presentation materials, while at the second meeting, the preparation of practicum reports became the indicator of communication skills with the highest score.

The average result of students' achievement in scientific communication skills showed a different percentage of the two aspects of skills. Bearing in mind that there were two aspects of communication skills measured through the implementation of the ICARE learning model, namely scientific writing and knowledge presentation. Each aspect of the skills was shown based on aspects of the material in straight motion in two meetings. Based on the findings of the presentation on scientific communication skills, achievement shows that after learning with the ICARE learning model, there was an increase in scores from the first meeting to the second meeting. This indicated that the ICARE learning model could optimize students' scientific 
communication skills. Stages that improve students' communication skills were at the connection stage in the chunk information activity. Besides doing chunk information practicum, it also requires students to read the findings of practicum in presentation activities. Student practicum activities lead to the making of practicum reports, which is one of the learning activities to practice communication skills, namely scientific writing, while reading the findings is one of the activities to train communication skills for the knowledge presentation aspect. Also, practicum activities at the connection stage require students to think of being a researcher. A researcher must be able to communicate the problem to be solved, how to get data, analyze the data obtained, and conclude the results through the language of scientific communication (Sasono, 2014).

Scientific communication skills for the scientific writing and knowledge presentation aspects were carried out by the observer by periodically observing the connection stages of the ICARE learning model. Students' scientific communication skills were measured individually by the observer during two meetings. Evaluation of the results of this observer included the results of student practicum reports (scientific writing) and presentation of student report results (knowledge presentation).

The scientific aspect of writing in two meetings has increased significantly. This can be seen from the increase in percentage from $38.83 \%$ to $90 \%$ in the first meeting. The ICARE learning model that had coherent and continuous characteristics from one stage to another was able to provide opportunities for students to solve problems faced coherently. Students were already able to choose various sources of references well, as well as facilitate students in preparing practicum reports. This can be seen from the results of reports of students who have followed, including aspects of the expected scientific method Connection stages require students to solve problems encountered. Through problem-solving at the stage of a good connection will build a good understanding of students' concepts. Students are expected to be able to analyze a problem well or have a good understanding of the concept will show good scientific communication in making conclusions (Sasono, 2014).

The improvement of student communication skills also occurred in the knowledge presentation aspect. This communication skill required students to develop and practice the report results in the form of a PowerPoint or poster and present the report in front of the class. The improvement of students' communication skills in the aspect of knowledge presentation increased from the first meeting to the second meeting. This was in line with the achievement of increasing scientific writing as well. Knowledge presentation requires students to have a basic ability to reason and argue well (Kulgemeyer, 2018). To communicate the findings in practicum properly, students surely need to master the contents and content well, understand the causal relationships contained in the content well one of the problems associated with scientific communication is teaching students to write scientific texts as a form of scientific communication (Suwono \& Dewi, 2019).

Generally, the ICARE learning model that was carried out in this study was very helpful for students to think and solve a problem. Each stage in the ICARE model led students to gain complete knowledge. Complete knowledge with good understanding skills can optimize student communication skills. ICARE is a learning model that maximizes each stage in building student concepts, including maximizing practicum activities. Learning models that maximize practicum activities can help students become active thinkers, not passive observers, thus building meaningful learning processes (Servitri \& Trisnawaty, 2018). From this meaningful learning process, it increases students' confidence in communicating their findings both in writing in the form of scientific 
writing and knowledge presentation (Buxton et al., 2018). Thus, based on the findings, it can be concluded that the ICARE learning model can improve students' scientific communication skills for the scientific writing and knowledge presentation aspects.

Tabel 2. Recapitulation of students' collaboration skills assessment result

\begin{tabular}{cccl}
\hline Meeting & $\begin{array}{c}\text { Total } \\
\text { Score }\end{array}$ & $\begin{array}{c}\text { Average } \\
\text { Score }\end{array}$ & Category \\
\hline 1 & 263 & 7.87 & Very poor \\
2 & 478 & 15.93 & Good \\
\hline
\end{tabular}

The recapitulation of students' collaboration skills assessment result was shown in table 2. Based on table 2, there was an increase in the number of scores and the average collaboration skills of students from each of them. In the first meeting, compared to the second meeting, there was a very significant increase in score of 215 with an average increase of 8.05 . With this increase, there was a change in the category of very poor categories, to become a good category. The results of these improvements indicated that an increase in collaboration skills when implemented ICARE learning models.

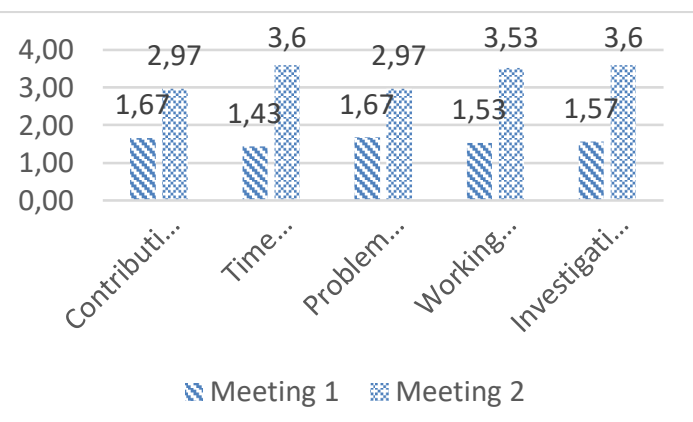

Figure 5. The recapitulation results of the collaboration for each aspect

The improvement in collaboration skills can also be seen in every aspect. The recapitulation of skills improvement in every aspect can be seen in Figure 5. It demonstrated that every aspect of collaboration has increased from meeting 1 to meeting 2. The highest increase was seen in the aspect of time management. The first meeting average for the aspect of time management was 1.43 , with a maximum score of 4 . The increase occurred at the 2 nd meeting to 3.60 , with an average value of an increase of 2.17. The aspects of the contribution and aspects of problem-solving became aspects with the lowest increase. At the first meeting, the two aspects had an average value of 1.67. The average value of the second meeting on aspects of the contribution and problem solving increased to 2.97 , with an increased value of 1.30 .

Table 3 Profile of interpretation of collaboration skills

\begin{tabular}{|c|c|c|c|c|c|c|c|}
\hline \multirow{2}{*}{ No } & \multirow{2}{*}{$\begin{array}{c}\text { Interpreta } \\
\text { tion of } \\
\text { Collabora } \\
\text { tion Skill }\end{array}$} & \multirow{2}{*}{$\begin{array}{c}\text { Meeting } \\
1 \\
\text { Code of } \\
\text { Student }\end{array}$} & \multicolumn{5}{|c|}{ Meeting 2} \\
\hline & & & $\mathbf{f}$ & $(\%)$ & $\begin{array}{l}\text { Code of } \\
\text { Student }\end{array}$ & f & $(\%)$ \\
\hline 1 & Very poor & $\begin{array}{c}\text { A1, A2, } \\
\text { A4, B1, } \\
\text { B2, B3, } \\
\text { B4, B5, } \\
\text { C2, C3, } \\
\text { C4, D1, } \\
\text { D2, D4, } \\
\text { E1,E4, } \\
\text { F1,F2, } \\
\text { F3 }\end{array}$ & 19 & 63.33 & - & 0 & 0 \\
\hline 2 & poor & $\begin{array}{c}\text { A3, C1, } \\
\text { C5, D3, } \\
\text { D5, E2, } \\
\text { E3, E5, } \\
\text { F4,F5 }\end{array}$ & 10 & 33.33 & - & 0 & 0 \\
\hline 3 & Enough & A5 & 1 & 3.33 & $\begin{array}{c}\text { A4, B3, } \\
\text { B5, C2, } \\
\text { D1, E1, } \\
\text { E3, F1 }\end{array}$ & 8 & 26.67 \\
\hline & & & & & $\begin{array}{l}A 1, A 2, \\
A 3, B 1, \\
B 2, \\
C 3, C 4, C\end{array}$ & & \\
\hline 4 & Good & - & 0 & 0 & $\begin{array}{l}\text { 5,D2, } \\
\text { D3, D4, } \\
\text { E4,E5, } \\
\text { F2, F3, } \\
\text { F5 }\end{array}$ & 15 & 50.00 \\
\hline 5 & Very Good & - & 0 & 0 & $\begin{array}{l}\text { A5, B4, } \\
\text { C1, D5, } \\
\text { E2, F4 }\end{array}$ & 6 & 20.00 \\
\hline
\end{tabular}

The profile of collaboration skills of each student for each category of interpretation of collaboration skills can be seen in table 3. It shows that collaboration skills improved based on increased interpretation. At the first meeting of 30 students, $63.33 \%$ were in very poor interpretation. Improved collaboration skills can be seen at the second meeting with a percentage of $50 \%$ of students already in the good category, and $20 \%$ already in the very good category. This finding reinforced that an increase in student collaboration skills after the ICARE learning model was carried out. 
In general, after implementing the ICARE learning model at two meetings, collaboration skills have improved both in terms of average and in terms of categories. At the first meeting, the average value of collaboration skills was at 7.87 , with a very poor category. The increase occurred at the second meeting with an average score of 15.93 in the good category. Besides, if we review each collaboration indicator consisting of 1) Contributions; 2) Time Management; 3) Problem Solving; 4) Working with others; 5) Investigation techniques also experience an increase, with the highest score at the second meeting reaching 3.6 of the score a maximum of 4 for the category of time management and investigation techniques. This indicated that the implementation of the ICARE learning model allowed students to collaborate and help each other in solving problems given in practical activities. In this study, the stages in the learning model that most practice collaboration skills are resistant to connections. One part of the connection stage is chunk information, where this stage requires students to find information through practical activities. Practicum activities at this stage require students to solve problems presented by the teacher.

The ICARE learning model implementation in practicing collaborative skills at the first meeting, the average score was 7.87, with the results of the interpretation included in the less category. At the first meeting, students are still not accustomed to solving problems in groups. This can be seen based on the results of observations at the first meeting of each category of collaboration skills are still at a low average with the lowest score is time management with a score of 1.43 from the maximum score 4. In the learning process, it appears that each group is still dominated by some students who are considered smart or considered able to solve the problem presented. Whereas in chunk information activities, students are given solid assignments, because in addition to practicum, students are also required to complete worksheets and practicum reports to require students to collaborate well with fellow group members.

At the second meeting, there was a significant increase in collaboration skills. Even so, there are still indicators of collaboration skills that the average score is still low, namely the indicators of contribution and problem-solving with a score of 2.97 from the maximum score of 4 . This happens, in the connection stage of chunk information activities through practicums, each group member is still some rely on each other. The results of the observation showed that the average group did not divide the tasks so that the group's contribution was uneven. The same thing with problem-solving. Each group was still not independent in solving problems. When given a problem, students still tended to ask the teacher or other group members, so there is no variation in solving problems.

The highest indicator of collaboration skills was the time management indicator, which increased from an average score of 1.43 at the first meeting to 3.6 at the second meeting. This was obtained based on the results of observations. Students seemed to be motivated to do practical work more efficiently than the first meeting because they were given an additional reward of value for the group that completes the assignment first. This was very influential in the activity of practicum activities because each group member performs activities effectively and quickly following the tasks shared by the group.

Learning like this can improve student collaboration skills because students are required to work together with in-group members (Fuad et al. 2019). In the process, collaboration skills were also able to improve students' other abilities (Ritter et al. 2018). With increased collaboration skills, students can interact well with each other's knowledge sharing (Le et al., 2018). Thus, if students' collaborative skills increased, it was expected that the ability to understand 
student concepts would increase, thereby increasing student learning outcomes.

Collaboration skills are needed to be trained in learning activities (Griiffin \& Care, 2018). Collaboration skills become one of the skills needed by students in the world of work in the $21^{\text {st }}$ century. Through collaboration skills, students are expected to survive in facing the challenges of the $21^{\text {st }}$ century that require a person to be able to work with others (Ridwan et al., 2018). As important as collaboration skills are, learning processes require learning models that practice collaboration skills.

Thus, based on the findings of the study, it can be illustrated that in general, collaboration skills after implementing the ICARE learning model were seen from the average score. This indicated that the ICARE learning model could be a means of practicing collaborative skills even if it was viewed based on individual students, there were still students who were inactive and have not been able to collaborate optimally.

\section{CONCLUSION}

The Introduction, Connection, Application, Reflection, and Extension (ICARE) learning model has been applied to physics learning activities in senior high schools to enhance students' communication and collaboration skills. The results showed that the students' communication skills in report-writing increased from the average of 1.53 at the first meeting to 3.6 at the second meeting, for aspects of making presentation material increased from 1.67 to 3.17 and the oral presentation aspect increased from 1.53 to 3.53 at the second meeting. Students' ability to collaborate with their peers also increased by an average score of 7.87 at the first meeting to 15.93 at the second meeting. From these results, we conclude that the ICARE learning model could improve the students' communication and collaboration skills. And we also suggest that the ICARE learning model can be an alternative learning model for practicing student communication and collaboration skills.

\section{ACKNOWLEDGMENT}

This work was financially supported by "Hibah Penelitian Bidang Ilmu, Sekolah Pasca Sarjana Universitas Pendidikan Indonesia" in the fiscal year of 2019.

\section{AUTHOR CONTRIBUTIONS}

ES reviewing literature and conceptualization. PS and ED collected, analysed data. PS prepared research design.

\section{REFERENCES}

Anagnostopoulou, K., Hatzinikita, V., \& Christidou, V. (2010). Assessed students' competencies in the greek school framework and the PISA survey. Review of Science, Mathematics and ICT Education, 4(2), 43-61.

Asri, Y. N., Rusdiana, D., \& Feranie, S. (2016). ICARE model integrated with science magic to improvement of students' cognitive competence in heat and temperature subject. Advances in Social Science, Education and Humanities Research, 57 (ICMSEd 2016), 137-139. https://doi.org/10.2991/icmsed16.2017.30

Buxton, C., Cardozo Gaibisso, L., Xia, Y., \& Li, J. (2018). How perspectives from linguistically diverse classrooms can help all students unlock the language of science. In L. Bryan \& K. Tobin (Eds.). 13 Questions: Reframing Education's Conversation: Science. New York: Peter Lang, 273-291.

Byrum, D. (2013). Instructional module development using the ICARE model with novice designers. In R. McBride \& M. Searson (Eds.), Proceedings of Society for Information Technology \& Teacher Education International Conference. Chesapeake, VA: Association for the Advancement of Computing in Education (AACE), 5016-5022.

Carni, Maknum, J., \& Siahaan, P. (2016). An implementation of ICARE approach (introduction, connection, application, 
reflection, extention) to improve the creative thinking skill. Journal of Physics: Conference Series, 755(1). https://doi.org/10.1088/17426596/755/1/011001

Chaiphugdee, D. (2019). ICARE model: Learning model organization that based on work skills through saori weaving for special needs children. Management Studies, $\quad 7(4), \quad 372-377$. https://doi.org/10.17265/23282185/2019.04.012

Creswell, J. W. (2014). Research design: Qualitative, quantitative and mixed methods approaches (4th ed.). Thousand Oaks, CA: Sage. https://doi.org/10.5539/elt.v12n5p40

Fuad, A. Z., Alfin, J., Fauzan, Astutik, S., \& Prahani, B. K. (2019). Group science learning model to improve collaborative problem solving skills and selfconfidence of primary school teacher candidates. International Journal of Instruction, 12(3), 119-132. https://doi.org/10.29333/iji.2019.1238a

Griiffin, P \& Care, E. (2018). Assessment and teaching of 21st century skills (pp. 17-66). Springer: Netherlands.

Hansah, F., Yulianti, D., \& Sugiyanto, S. (2013). Pembelajaran fisika menggunakan better teaching and learning berketerampilan proses untuk meningkatkan aktivitas belajar siswa SMP. UPEJ Unnes Physics Education Journal. 2(3), 61-67.

Kulgemeyer, C. (2018). Impact of Secondary Students' Content Knowledge on Their Communication Skills in Science. International Journal of Science and Mathematics Education, 16(1), 89-108. https://doi.org/10.1007/s10763-0169762-6

Le, H., Janssen, J., \& Wubbels, T. (2018). Collaborative learning practices: teacher and student perceived obstacles to effective student collaboration. Cambridge Journal of Education, 48(1), 103-122.

https://doi.org/10.1080/0305764X.2016
.1259389

Qian, M., \& Clark, K. R. (2016). Gamebased Learning and 21st century skills: A review of recent research. Computers in Human Behavior, 63, 50-58. https://doi.org/10.1016/j.chb.2016.05.0 23

Ridwan, A., Rahmawati, Y., \& Hadinugrahaningsih, T. (2017). STEAM integration in chemistry learning for developing 21st century skills. MIER Journal of Educational Studies, Trends \& Practices, 7(2), 184194.

Ritter, B. A., Small, E. E., Mortimer, J. W., \& Doll, J. L. (2018). Designing management curriculum for workplace readiness: Developing students' soft skills. Journal of Management Education, 42(1), 80-103. https://doi.org/10.1177/1052562917703 679

Salyers, V., Carter, L., Barrett, P., \& Williams, L. (2010). Evaluating student and faculty satisfaction with a pedagogical framework. The Journal of Distance Education/ Revue de l'Éducation à Distance, 24(3).

Sasono, M. (2014). pengembangan model pembelajaran kooperatif jigsaw yang berorientasi pada keterampilan komunikasi ilmiah mahasiswa dalam matakuliah fisika kuantum. Jurnal Edukasi Matematika dan Sains, 2(2). https://doi.org/10.25273/jems.v2i2.224

Servitri, M. O., \& Trisnawaty, W. (2018). The development of inquiry science worksheet to facilitate the process skills. Journal of Education and Learning (EduLearn), $\quad$ 12(4), 575. https://doi.org/10.11591/edulearn.v12i4 .8937

Sinuraya, J., Panggabean, D. D., \& Wahyuni, I. (2019). Quality effectiveness analysis assessment of physics teaching materials-oriented ICARE method on student cognitive mastery based experiment skill level. Asian Journal of Education and Social Studies, 5(3), 1-9. 
https://doi.org/10.9734/ajess/2019/v5i3 30145

Sinuraya, J., Wahyuni, I., Demonta Panggabean, D., \& Tarigan, R. (2019).

Optimize use of icare based student worksheet (ICARE-BSW) in physics learning at the introduction level. Journal of Physics: Conference Series, 1317(1). https://doi.org/10.1088/17426596/1317/1/012161

Spektor-Levy, O., Eylon, B. \& Scherz, Z. (2008). Teaching communication skills in science: Tracing teacher change. Teaching and Teacher Education, 24, 462-477

Suwono, H., \& Dewi, E. K. (2019). Problembased learning blended with online interaction to improve motivation, scientific communication and higher order thinking skills of high school students. AIP Conference Proceedings 2081(2019), 030003.

Thunkam, P., Donpudsa, S., \& Dornbundit, P. (2016). Development of STEM activities in chemistry on "protein"to enhance 21st century learning skills for Senior High School Students. Silpakorn University Journal of Social Sciences, Humanities, and Arts. 16(3), 217-234.

Tikollah, M. R., Hasyim, S. H., \& Tangke, S. (2019). Combination of PBL and I CARE learning models in increasing student learning activities. Advances in Social Science, Education and Humanities Research, 335, 530-535 